\title{
PENGETAHUAN IBU TENTANG TANDA BAHAYA KEHAMILAN DENGAN MEDIA APLIKASI SAHABAT IBU HAMIL (ASIH)
}

\author{
Dewi Nurdianti* \\ *Program Studi DIII Kebidanan Fakultas IImu Kesehatan Universitas Muhammadiyah Tasikmalaya \\ email: dewinurdianti87@gmail.com
}

\section{ABSTRACT KNOWLEDGE OF THE DANGER OF PREGNANCY WITH PREGNANT WOMEN'S FRIENDS MEDIA (ASIH)}

Background: Lack of early detection in recognizing danger signs of pregnancy and risk factors in pregnancy can result in a lack of rapid anticipation between pregnancy and delivery, so there is a great risk of maternal death. . The application of Mobile Health Information Technology (mHealth) in improving health services for pregnant women is an alternative solution that can assist in providing information and health education for pregnant women to increase knowledge in recognizing pregnancy danger signs.

Purpose: This study aims to determine the increase in knowledge of pregnant women after being given the Pregnant Mother's Friend Application (ASIH) in the Purbaratu Health Center, Tasikmalaya City.

Methods: This type of pre-experimental research was one group pretest-posttest, the sampling technique used consecutive sampling, and the sample size was 32 pregnant women. The population in this study were trimester 1-3 pregnant women.

Results: The results of the calculation of maternal knowledge were mostly with good knowledge categories as many as 24 people (75\%) and sufficient knowledge as many as 8 people (25\%).

Conclusion: Maternal knowledge increases about the danger signs of pregnancy after being given the Aplikasi Sahabat Ibu Hamil (ASIH).

Suggestion: Knowledge of the danger signs of pregnancy should be improved by using the buku KIA or other information media, one of which is the pregnant mother application

Keywords: Knowledge, Counter for danger Signs of Pregnancy, Aplikasi Sahabat Ibu Hamil

\section{ABSTRAK}

Latar Belakang : Kurangnya deteksi dini mengenali tanda-tanda bahaya kehamilan dan faktor-faktor risiko pada kehamilan dapat mengakibatkan kurangnya antisipasi yang cepat pada saat kehamilan sampai proses persalinan sehingga berisiko besar terjadinya kematian ibu. . Penerapan Teknologi Informasi Mobile Health (mHealth) dalam peningkatan pelayanan kesehatan pada ibu hamil merupakan salah satu solusi alternatif yang dapat dapat membantu dalam memberikan informasi dan edukasi kesehatan bagi ibu hamil untuk meningkatkan pengetahuan dalam mengenal dalam mengenal tanda bahaya kehamilan.

Tujuan : Penelitian ini bertujuan untuk mengetahui peningkatan pengetahuan ibu hamil setelah di berikan Aplikasi Sahabat Ibu Hamil (ASIH) di Wilayah Kerja Puskesmas Purbaratu Kota Tasikmalaya.

Metode : Jenis penelitian pre eksperimental dengan tipe one group pretest-postest, teknik sampling menggunakan consecutive sampling, dengan perhitungan besar sampel diperoleh sebanyak 32 ibu hamil. Populasi pada penelitian ini adalah ibu hamil Trimester 1-3.

Hasil : Hasil perhitungan pengetahuan ibu sebagian besar dengan kategori pengetahuan baik sebanyak 24 orang $(75 \%)$ dan pengetahuan cukup sebanyak 8 orang $(25 \%)$.

Kesimpulan:Tingkat Pengetahuan lbu hamil mengenai tanda bahaya kehamilan sebagain besar berpengetahuan baik setelah diberikan media Aplikasi Sahabat Ibu Hamil (ASIH) .

Saran : Pengetahuan tanda bahaya kehamilan harus terus ditingkatakan dengan menanfaatkan buku KIA atau media informasi lain salah satunya aplikasi ibu hamil.

Kata Kunci : Pengetahuan, Tanda Bahaya Kehamailan, Aplikasi Sahabat Ibu Hamil 


\section{PENDAHULUAN}

Penurunan AKI di Indonesia terjadi sejak tahun 1991 sampai dengan 2007, yaitu dari 390 menjadi 228 per 100.000 kelahiran hidup.SDKI tahun 2012 menunjukkan peningkatan AKI yang signifikan yaitu menjadi 359 kematian ibu per 100.000 kelahiran hidup. AKI kembali menujukkan penurunan menjadi 305 kematian ibu per 100.000 kelahiran hidup berdasarkan hasil Survei Penduduk Antar Sensus (SUPAS) 2015. World Health Organisation (WHO) memperkirakan bahwa sebagian besar dari kematian ini bisa dihindari dengan akses dan kualitas pelayanan antenatal yang efektif (SDKI, 2012; WHO, 2015)

Penyebab AKI dapat diturunkan dan dicegah melalui pemberian asuhan kehamilan yang rutin dan berkualitas untuk mendeteksi secara dini adanya kelainan dan komplikasi. Selain itu ibu hamil juga harus mengetahui tentang tanda bahaya kehamilan. Apabila ibu mengetahui tentang tanda bahaya kehamilan, ibu akan selalu waspada dan berhati-hati dengan cara selalu rutin memeriksakan kehamilannya. Kurangnya deteksi dini mengenali tanda-tanda bahaya kehamilan dan faktor-faktor risiko pada kehamilan dapat mengakibatkan kurangnya antisipasi yang cepat pada saat kehamilan sampai proses persalinan sehingga berisiko besar terjadinya kematian ibu(Irianti et al., 2014)

Berkembangnya teknologi informasi dan komunikasi yang semakin pesat, mendorong adanya inovasi dan perubahan yang melibatkan eksperimen dalam berbagai bidang, termasuk bidang kesehatan yang menerapkan penggunaan computer atau pun berbasis android dalam kegiatannya atau yang biasa dikenal dengan istilah $\mathrm{E}$-Health. Kondisi geografis Indonesia yang menyebar merupakan peluang sekaligus tantangan bagi pemerintah. Beragam kekayaan dan potensi daerah merupakan aset yang tak ternilai harganya. Namun di balik kekayaan tersebut tersimpan berjuta tantangan pemerataan infrastruktur menuju masyarakat sejahtera hingga satu daerah dengan daerah lainnya dapat tumbuh bersama dengan karakteristik dan keunikan yang dimiliki(Sumekar, Thamrin, \& Arik, 2015).

Perkembangan tekhnologi informasi pada perangkat bergerak saat ini berkembang pesat, hal ini dapat menjadi salah satu sarana bagi ibu hamil untuk memperoleh informasi. Salah satu perkembangan teknologi yang dapat digunakan dalam meningkatkan pendidikan kesehatan yaitu penggunaan smartphone. Pada tahun 2014 jumlah pengguna smartphone sebanyak 45 juta pengguna dan pada tahun 2015 mengalami peningkatan mencapai 56 juta pengguna. Hasil studi pendahuluan yang dilakukan diperoleh bahwa 96\% bidan dan 87 $\%$ ibu hamil memiliki smartphone berbasis android(Dag Bjornland, Eugene Goh, Haanæs, Kainua, \& Kennedy, 2012).

Secara tidak langsung kematian ibu dapat dipengaruhi oleh keterlambatan mengenali tanda bahaya dan membuat keputusan untuk segera mencari pertolongan, keterlambatan mencapai fasilitas kesehatan dan terlambat mendapat pertolongan pelayanan kesehatan. Oleh karenanya deteksi dini oleh tenaga kesehatan dan masyarakat tentang adanya faktor risiko dan komplikasi, serta penanganan yang adekuat sedini mungkin, merupakan kunci keberhasilan dalam penurunan angka kematian ibu dan bayi yang dilahirkannya(Bogale \& Markos, 2015)

Tanda bahaya kehamilan, persalinan dan nifas harus ditangani dan dideteksi sejak dini dengan benar karena setiap tanda bahaya kehamilan, persalinan dan nifas bisa mengakibatkan komplikasi pada masa hamil, persalinan dan masa nifas. Kurangnya pengetahuan ibu tentang tanda bahaya kehamilan, akan mempengaruhi juga sikap ibu dalam menanggapi tanda dan bahaya selama kehamilan, persalinan dan nifas. Sehingga ibu tidak dapat melakukan identifikasi terhadap tanda-tanda yang nampak sehingga tidak dapat melakukan antisipasi secara dini (Sumarni, Rahma, \& Ikhsan, 2014).

Penerapan Teknologi Informasi Mobile Health (mHealth) dalam peningkatan pelayanan kesehatan pada ibu hamil merupakan salah satu solusi alternatif yang dapat dapat membantu dalam memberikan informasi dan edukasi kesehatan bag ibu hamil tanpa dibatasi ruang dan waktu dan tanpa harus bertatap muka langsung dengan tenaga kesehatan khususnya bidan sebagai tonggak pemberi pelayanan yang paling banyak dikunjungi oleh ibu hamil (Ghanylsmaeel \& Khadhm Jabar, 2013)

Aplikasi smartphone memungkinkan bagi ibu untuk mengakses layanan kesehatan yang mereka butuhkan, membantu pertolongan pertama sekaligus menghubungi tenaga kesehatan dan membantu pengguna untuk menjawab keluhan seputar kehamilan (Oyeyemi \& Wynn, 2014).

\section{METODE PENELITIAN}

Jenis penelitian pre eksperimental dengan tipe one group pretest-postest, teknik sampling menggunakan consecutive sampling, dengan perhitungan besar sampel diperoleh sebanyak 32 ibu 
hamil. Populasi pada penelitian ini adalah ibu hamil Trimester I,II,III sebanyak 32 orang.Kriterian inklusi pada penelitian ini adalah Ibu hamil dalam keadaan sehat, Ibu hamil memiliki jenis handphone smartphone dan bisa menggunakannya, bersedia menjadi subjek penelitian dengan menandatangani persetujuan setelah penjelasan Penelitian ini dilakukan di Wilayah Kerja Puskesmas Purbaratu Kota Tasikmalaya

HASIL

Penelitian ini dilaksanakan pada bulan Februari - Maret 2019 di Wilayah Kerja Puskesmas Purbarau Kota Tasikmalaya Proses penelitian dilakukan dengan mengidentifikasi ibu hamil yang memenuhi kriteria inklusi sehingga didapatkan sebanyak 32 ibu hamil yang telah menandatangani lembar persetujuan subjek penelitian

Tabel 1.

Karakteristik Subjek Kelompok Penelitian

\begin{tabular}{lcc}
\hline \multirow{2}{*}{ Karakteristik } & \multicolumn{2}{c}{ Frekuensi } \\
\cline { 2 - 3 } & $\mathbf{n = 3 2}$ & Persentase \\
\hline Usia & & \\
$<20$ tahun & 1 & $3,1 \%$ \\
$20-35$ tahun & 25 & $78,1 \%$ \\
$>35$ tahun & 6 & $18,8 \%$ \\
\hline Pendidikan & & \\
Dasar & 25 & $78,1 \%$ \\
Menengah & 4 & $12,5 \%$ \\
Atas & 3 & $9,4 \%$ \\
\hline Paritas & & \\
Primipara & 9 & $28,1 \%$ \\
Multipara & 20 & $62,5 \%$ \\
grandemultipara & 3 & $9,4 \%$ \\
\hline Pekerjaan & & \\
bekerja & 1 & $3,1 \%$ \\
tidak bekerja & 31 & $96,9 \%$ \\
\hline
\end{tabular}

Dari tabel 1 karakteristik berdsarakan usia $178,1 \%$ berusia $20-35$ tahun, karakteristik berdasarakan pendidikan $78,1 \%$ tingkat pendidikan responden adalah dasar. Karakteristik responden berdasarkan paritas $62,5 \%$ responden memiliki anak lebih dari satu dan ibu hamil yang tidak bekerja $96,9 \%$.

Tabel 2.

Distribusi Frekuensi Kategori Skor Pre Test Tanda Bahaya Kehamilan

\begin{tabular}{lcc}
\hline & $\mathbf{F}$ & $\%$ \\
\hline Baik & 5 & 15.6 \\
Cukup & 17 & 53.1
\end{tabular}

\begin{tabular}{lll} 
Kurang & 10 & 31.3 \\
\hline Total & 32 & 100 \\
\hline
\end{tabular}

Dari tabel 2 memperlihatkan bahwa hasil pre test ibu mengenai tanda bahaya kehamilan sebagaian besar pada ketegori cukup yaitu 17 orang $(53,1 \%)$ dan pada ketegori kurang yaitu 10 orang $(31,3 \%)$.

Tabel 3.

Distribusi Frekuensi Kategori Skor Post Test Tanda Bahaya Kehamilan

\begin{tabular}{lcc}
\hline & $F$ & $\%$ \\
\hline Baik & 24 & 75 \\
Cukup & 8 & 25 \\
Kurang & 0 & 0 \\
\hline Total & 32 & 100 \\
\hline
\end{tabular}

Dari tabel 3 memperlihatkan bahwa hasil pos test ibu mengenai tanda bahaya kehamilan sebagaian besar pada ketegori baik yaitu 24 orang $(75 \%)$ dan pada ketegori baik yaitu 8 orang $(25 \%)$.

\section{PEMBAHASAN}

Berdasarkan tabel 1 Karakteristik, subjek pada penelitian ini adalah ibu hamil trimester I,II,III yang berjumlah 32 orang di wilayah kerja Puskesmas Purbaratu, Karakteristik diantaranya yaitu usia ibu hamil, pendidikan , paritas dan pekerjaan. Penelitian ini dilaksanakan pada wilayah kerja puskesmas Purbaratu Kota Tasikmalaya. Dari tabel 1 karakteristik berdsarakan usia 78,1\% berusia 20-35 tahun, karakteristik berdasarakan pendidikan $78,1 \%$ tingkat pendidikan responden adalah pendidikan dasar. Karakteristik responden berdasarkan paritas $62,5 \%$ responden multigravida dan ibu hamil yang tidak bekerja $96,9 \%$.

Dari tabel 2 dapat dilihat hasil pre test sebagaian besar pada ketegori cukup yaitu 17 orang $(53,1 \%)$ dan pada ketegori kurang yaitu 10 orang (31,3\%).Pengetahuan adalah hasil penginderaan manusia, atau hasil tahu seseorang terhadap objek melalui indera yang dimilikinya (mata, hidung, telinga, dan sebagainya). Dengan sendirinya, pada waktu penginderaan sampai menghasilkan pengetahuan tersebut sangat dipengaruhi oleh intensitas perhatian dan persepsi terhadap objek. Sebagian besar pengetahuan seseorang diperoleh melalui indera pendengaran (telinga), dan indera penglihatan (mata)(Notoatmodjo, 2012).

Hasil penelitian yang dilakukan oleh (Hailu \& Berhe, 2014) di Ethiopia 2010 menunjukkan bahwa hasil dari 743 wanita hamil yang berpartisipasi dalam penelitian ini, terdapat $226(30,4 \%), 305(41,3 \%)$ dan 
$279(37,7 \%)$ tahu setidaknya dua tanda bahaya selama kehamilan, persalinan dan masa nifas. Penelitian ini menunjukkan bahwa tingkat pengetahuan ibu hamil tentang tanda bahaya kebidanan (selama kehamilan, persalinan dan masa nifas) adalah rendah yang dipengaruhi oleh daerah tempat tinggal ibu hamil.

Tabel 3 hasil post test sebagaian besar pada ketegori baik yaitu 24 orang (75\%) dan pada ketegori cukup yaitu 8 orang (25\%). Pada penelitian ini menunjukan adanya peningkatan pengetahuan setelah post test bila dibandingkan dengan pre test, hal ini dapat dijelaskan karena ibu hamil mengunduh aplikasi sahabat lbu hamil yang berisi informasi seputar kehamilan dan dapat membacanya sesuai keinginan dan dapat langsung berkonsultasi dengan bidan.Hal ini yang menyebabkan peningkatan pengetahuan mengenai tanda bahaya kehamilan.Aplikasi Sahabat Ibu Hamil dirancang berisikan informasi kehamilan yang mudah dipahami,bahasa yang sederhana,tampilan aplikasi yang menarik, tampilan gambar sesuai dengan meteri yang disampaikan.

Berdasarkan penelitian yang dilakukan (Oyeyemi \& Wynn, 2014) menunjukkan bahwa pemanfaatan teknologi smartphone (ponsel) bisa memperkuat sistem kesehatan primer dan meningkatkan akses pelayanan kesehatan bagi ibu hamil. Aplikasi smartphone memungkinkan bagi ibu untuk mengakses layanan kesehatan yang mereka butuhkan, membantu pertolongan pertama sekaligus menghubungi tenaga kesehatan dan membantu pengguna untuk menjawab keluhan seputar kehamilan. bahwa tingkat kepuasan ibu hamil yang didukung dengan menggunakan Short Message Service (SMS) Mobile Phone lebih tinggi $(9,25 \%)$ dibanding yang tidak menerima SMS $(8,00 \%)$ selama periode antenatal sehingga dapat meningkatkan kepercayaan dan mengurangi kecemasan ibu hamil.

Informasi tentang kehamilan dan perkembangan janin adalah aspek yang paling penting dari aplikasi smartphone. Survei mengungkapkan bahwa hampir semua responden menggunakan beberapa bentuk media online untuk kehamilan atau informasi pengasuhan dan dukungan. Penggunaan aplikasi smartphone merupakan peringkat tertinggi sebagai bentuk keterlibatan digital selama kehamilan yang dapat meningkatkan pengetahuan ibu hamil. Penggunaan smartphone dalam mengenal tanda bahaya kehamilan sangat mempengaruhi ibu dalam meningkatkan pengetahuannya sehingga dengan penggunaan aplikasi smartphone menyebabkan ibu mampu untuk melakukan deteksi dini terhadap kehamilannya dan dapat menghindari terjadinya komplikasi selama kehamilan, persalinan dan nifas(Mbithi \& Onderi, 2016).

Hasil penelitian ini juga dipertegas dengan teori yang yang menyatakan banyaknya pengetahuan kurang baik disebabkan oleh berbagai faktor yaitu pendidikan dan kurangnya informasi yang didapat oleh responden sehingga pengetahuan sangat berdampak terhadap seseorang dalam bertindak. Pengetahuan merupakan faktor penting dalam menentukan perilaku seseorang karena pengetahuan dapat menimbulkan perubahan persepsi, kebiasaan masyarakat termasuk didalamnya dalam bertindak. Pembentukan sikap seseorang juga dipengaruhi oleh tingkat pengetahuan. Semakin tinggi pengetahuan seseorang maka semakin baik pula sikap seseorang dalam menghadapi masalah. Pengetahuan mempunyai keeratan hubungan dengan mengenal tanda bahaya kehamilan, artinya semakin baik pengatahuan ibu maka kecenderungan ibu untuk melakukan tindakan deteksi dini tanda bahaya kehamilan akan semakin besar(Notoatmodjo, 2012).

Salah satu contoh tanda bahaya kehamilan adalah bentuk pergerakan janin. Pada aplikasi ini, ibu diberikan informasi untuk mengetahui cara pemantauan pergerakan janin. Ibu dapat merasakan kondisi kesehatan bayi dari pergerakan janinnya, sehingga apabila ditemukan suatu kondisi dimana ibu tidak dapat merasakan pergerakan janin dalam waktu tertentu, ibu dapat segera meminta pertolongan ke tenaga kesehatan(Wiknjosastro $\mathrm{H}$. IImu kebidanan., 2005).

Pemanfaatan teknologi informasi menjadi sangat penting sebab terbukti bahwa dengan menggunakan teknologi informasi, efektivitas dan efisiensi dalam melakukan sebuah proses lebih cepat dapat dicapai. Disisi lain keterbatasan waktu bidan dalam memberikan asuhan antenatal termasuk pemberian pendidikan kesehatan juga berpengaruh terhadap kualitas layanan antenatal. Dengan adanya informasi yang cepat dan berkualitas diharapkan pelayanan kesehatan dapat ditingkatkan. Selain itu, meningkatkan akses terhadap perawatan antenatal untuk ibu merupakan solusi untuk mencegah atau menangani komplikasi maternal secara signifikan. Perawatan antenatal dianggap menjadi salah satu perawatan penting untuk kehamilan yang sehat(Oyeyemi \& Wynn, 2014).

\section{KESIMPULAN}

Kesimpulan pada penelitian ini terdapat peningkatan pengetahuan pada ibu hamil mengenai 
tanda bahaya kehamilan setelah diberikan aplikasi sahabat ibu hamil (ASIH).

\section{SARAN}

Aplikasi Sahabat Ibu Hamil dapat digunakan sebagai media pendidikan kesehatan mengenai informasi kehamilan bagi ibu hamil.

\section{DAFTAR PUSTAKA}

Bogale, D., \& Markos, D. (2015). Knowledge of obstetric danger signs among child bearing age women in Goba district, Ethiopia: A crosssectional study. BMC Pregnancy and Childbirth, 15(1), 1-8. https://doi.org/10.1186/s12884-015-0508-1

Dag Bjornland, Eugene Goh, Haanæs, K., Kainua, T., \& Kennedy, S. (2012). The SocioEconomic Impact of Mobile Health. BCG, (April), 1-49.

Ghanylsmaeel, A., \& Khadhm Jabar, E. (2013). Effective System for Pregnant Women using Mobile GIS. International Journal of Computer Applications, $\quad 64(11), \quad 1-7$. https://doi.org/10.5120/10675-5547

Irianti, B., Halida, M. E., Duhita, F., Prabandari, F., Yulianti, N., Hartiningtiyaswati, S., \& Anggraini, Y. (2014). Asuhan Kehamilan Berbasis Bukti. (F. Husin, Ed.) (1st ed.). Jakarta: Sagung Seto.

Mbithi, J., \& Onderi, J. (2016). A Smart Phone based Application for Early Detection of Pregnancy
Complications in Kenya. International Journal of Computer Applications, 147(10), 8-14. https://doi.org/10.5120/ijca2016911190

Notoatmodjo, S. (2012). Ilmu Perilaku Kesehatan. Jakarta: Rineka Cipta.

Oyeyemi, S. O., \& Wynn, R. (2014). Giving cell phones to pregnant women and improving services may increase primary health facility utilization: A case-control study of a Nigerian project. Reproductive Health, 11(1), 1-8. https://doi.org/10.1186/1742-4755-11-8

SDKI. (2012). Survei Demografi Dan Kesehatan Indonesia. Jakarta: Departemen Kesehatan.

Sumarni, Rahma, \& Ikhsan, M. (2014). The Relationship Of Knowledge And Attitude Of Pregnant Women About Dangerous Signs Of Pregnancy, Delivering And Postpartum Against Anc Behavior in Latambaga Health Center, Kolaka Regency.

Sumekar, G. A. D., Thamrin, I., \& Arik, F. (2015). APLIKASI PANDUAN KEHAMILAN DAN FORUM DISKUSI UNTUK IBU HAMIL BERBASIS ANDROID.

WHO. (2015). Pregnancy, Childbirth, Postpartum and Newborn Care. In Pregnancy, Childbirth, Postpartum and Newborn Care (Third Edit). Luxembourg: WHO.

Wiknjosastro H. IImu kebidanan. (2005). IImu kebidanan (Empat). Jakarta: Pt Bina Pustaka Sarwono Prawirohardjo. 